\title{
KAT8 wt Allele
}

National Cancer Institute

\section{Source}

National Cancer Institute. KAT8 wt Allele. NCI Thesaurus. Code C73659.

Human KAT 8 wt allele is located in the vicinity of $16 p 11.2$ and is approximately $14 \mathrm{~kb}$ in length. This allele, which encodes histone acetyltransferase KAT 8 protein, may play a role in activation of RNA polymerase II transcription. 